\title{
Monika Słupińska
}

Uniwersytet Łódzki

e-mail: mslupinska@uni.lodz.pl

\section{EUROPA W DOBIE KRYZYSU - \\ PRZEWIDYWANE SCENARIUSZE REFORM}

\section{EUROPE IN THE ERA OF CRISIS - EXPECTED REFORM SCENARIOS}

DOI: $10.15611 /$ pn.2017.498.29

JEL Classification: F02, F50, F55

Streszczenie: Dzisiejsza zjednoczona Europa jest w pewnym sensie zdezorganizowana, w niektórych państwach członkowskich obserwuje się rosnącą popularność różnego rodzaju ruchów nacjonalistycznych, populistycznych i demagogicznych, wzrost popularności partii wyraźnie antyeuropejskich. Nie ulega wątpliwości, że Unia Europejska wymaga reform. Podejmując dyskusję dotyczącą kierunków reform i przyszłego kształtu UE, reform jej instytucji, zasad działania i polityk, powinniśmy odwołać się przede wszystkim do pierwotnych przesłanek procesu powojennej integracji europejskiej - pragnienia zapewnienia Europie pokoju. Celem artykułu jest refleksja nad istotą integracji europejskiej i kierunkami ewentualnych reform UE. Omówione zostały potencjalne scenariusze reform, wraz ze wskazaniem najbardziej z nich prawdopodobnego, jakim jest Europa wielu prędkości. W artykule wykorzystano źródła, do których rzadko odwołują się autorzy tekstów naukowych - artykuły publikowane w prasie zagranicznej.

Słowa kluczowe: integracja, Unia Europejska, reformy.

Summary: Today's Europe is disorganised, in some Member States we can observe a rapidly growing popularity of different nationalist demagogues. After over 60 years of peace and harmony, the populists and the extreme right movements try to push Europe into the abyss of conflict. Especially at this time we should reflect more on the most important positive aspects of the European Union: freedom of movement, freedom of trade, protection of human rights, and protection of the environment. The aim of this article is to reflect on the essence of the European integration and the directions of possible EU reforms in the period of the crisis (caused by Brexit, and the growing popularity of nationalist and anti-European movements).

Keywords: integration, European Union, reforms. 


\section{Wstęp}

Unia Europejska jest niezwykłym projektem politycznym. Dzięki zainicjowanym w latach 50. ubiegłego wieku procesom integracyjnym w ciągu ostatnich 60 lat Unia Europejska określiła się jako jeden z głównych bloków gospodarki światowej, generując ok. 25\% światowego PKB, przy jednoczesnym zapewnianiu wysokich standardów w zakresie jakości życia. Mieszkańcy Unii Europejskiej, stanowiący 7\% populacji świata, są adresatami 50\% światowych wydatków socjalnych [European Commission 2017].

Ostatnie lata to czas, w którym zjednoczona Europa narażona jest na poważne zagrożenia, stawiające w niepewności przyszłość tego ugrupowania. Zewnętrzne i wewnętrzne czynniki stanowią zagrożenie dla stabilności i jedności Unii Europejskiej. Wymieniając niektóre: kryzys migracyjny, napięcie na wschodnich granicach (konflikt Rosja - Ukraina), sytuacja w Turcji, konflikty w basenie Morza Sródziemnego (Syria, Izrael - Palestyna, Libia) i terroryzm. Jedności europejskiej nie sprzyja fakt, że niektóre państwa członkowskie w sposób niewspółmiernie nieproporcjonalny odczuwają skutki kryzysu migracyjnego. Problemem jest także wzrost populizmu, nieprzestrzeganie wartości europejskich i reguł prawa przez takie państwa, jak Polska czy Węgry, oraz bezprecedensowa decyzja obywateli jednego z państw UE o wyjściu z Unii Europejskiej (Wielka Brytania). Zjednoczona Europa potrzebuje zatem roztropnej i przemyślanej reakcji na wszystkie te zjawiska, co oznacza konieczność podjęcia działań reformujących jej funkcjonowanie [de Zwaan 2016].

Podejmując rozważania nad kierunkami reform Unii Europejskiej należy przede wszystkim odwołać się do jej korzeni i zadać sobie pytanie: czym jest Unia Europejska i jakie jest jej znaczenie dla Europejczyków? Unia Europejska to ugrupowanie wolnych, suwerennych państw, przestrzegających wspólnie uzgodnionych zasad. Suwerenność jest nie tylko gwarantowana, ale podlega także ochronie w ramach prawa unijnego. Unia Europejska to pewnego rodzaju wartość, która wykształciła się nie „pomiędzy” państwami członkowskimi, ale niejako „ponad” nimi. To bezprecedensowy projekt polityczny, gospodarczy i społeczny, dzięki któremu Europa doświadcza właśnie najdłuższego w swojej historii okresu wolnego od wojen i konfliktów zbrojnych.

Podejmując dyskusję dotyczącą kierunków reform i przyszłego kształtu Unii Europejskiej, reform jej instytucji, zasad działania i polityk, powinniśmy odwołać się przede wszystkim do pierwotnych przesłanek procesu powojennej integracji europejskiej - pragnienia zapewnienia Europie pokoju.

Dzisiejsza Europa jest w pewnym sensie zdezorganizowana, obserwujemy dekompozycję dotychczasowego kształtu Unii Europejskiej i wartości ją budujących. W niektórych państwach członkowskich obserwuje się silny wzrost popularności różnego rodzaju demagogii nacjonalistycznych. Po niemal 60 latach pokoju i harmonii populiści i skrajnie prawicowe partie powodują zagrożenie zepchnięcia Europy w przepaść konfliktów narodowych. Unia Europejska nadal jest gwarantem bez- 
pieczeństwa i pokoju w Europie, dlatego też dalsza integracja winna być postrzegana jako wyzwanie, zadanie do osiągnięcia, w żadnym wypadku nie można rozpatrywać jej w kategoriach ,problemu”.

Szczególnie istotne w dobie obecnego kryzysu jest zwiększenie i upowszechnianie refleksji nad znaczeniem wartości będących owocem integracji europejskiej: swobody poruszania się, swobody handlu, ochrony praw człowieka czy wysiłków podejmowanych na rzecz ochrony środowiska. Dla krajów takich jak Polska bardzo ważnym aspektem członkostwa w Unii Europejskiej jest także solidarność, która realizowana jest przede wszystkim w ramach polityki spójności.

Celem artykułu jest podjęcie refleksji nad istotą procesu integracji europejskiej i kierunkami możliwych reform Unii Europejskiej w dobie problemów, z którymi Europa się boryka (brexit, rosnąca popularność ruchów nacjonalistycznych i antyeuropejskich).

\section{Rosnący populizm - główne zagrożenie dla jedności europejskiej}

To, czego doświadczamy obecnie w zjednoczonej Europie, to brak wspólnej, podzielanej przez wszystkie państwa członkowskie, wizji Unii Europejskiej. 27 pozostających w UE państw członkowskich ma bardzo różne historie i kultury, od społecznie liberalnych państw skandynawskich do bardziej religijnego i konserwatywnego Południa i Wschodu Europy ${ }^{1}$. Różnice te stały się szczególnie widoczne w dobie kryzysu uchodźczego, gdy Węgry i Słowacja twierdziły, że napływ imigrantów muzułmańskich grozi ich kulturze (podobnego zdania jest także duża część Polaków). Różnice w kulturze, historii i mentalności uwidaczniają się na różnych płaszczyznach współpracy europejskiej. Podział między byłymi krajami radzieckimi a resztą Europy ma na przykład duży wpływ na negocjacje dotyczące reakcji UE na rosyjską agresję [McDonald-Gibson 2016]. Istniejące różnice, podsycane przez ruchy demagogiczne, w połączeniu z istniejącymi problemami, z jakimi boryka się Unia Europejska, stanowią pożywkę dla nasilania się populizmu. W kilku krajach europejskich, w tym w Finlandii, na Węgrzech, Łotwie, Litwie, w Norwegii i Szwajcarii, partie prawicowe sięgnęły bądź były bliskie sięgnięcia po władzę. Nawet w przypadku gdy prawicowi populiści nie uzyskali władzy, partie, takie jak brytyjski UKIP, francuski Front National i niemiecka Alternative für Deutschland, hiszpański Podemos czy partia Niezależni Grecy, cieszyły się rekordową popularnością.

Dwa główne czynniki leżą u podstaw dzisiejszego narastającego populizmu: (1) kryzys migracyjny i (2) przedłużające się wychodzenie z kryzysu strefy euro. Rosnąca popularność partii populistycznych jest w pewnym sensie odpowiedzią społeczeństw na polityczne niepowodzenia partii mainstreamowych w niektórych

${ }^{1}$ Dania na przykład zalegalizowała związki seksualne tej samej płci w 1989 r., a Malta umożliwiła obywatelom rozwód dopiero w $2011 \mathrm{r}$. 
krajach. Jest to także forma emocjonalnej opozycji części Europejczyków wobec poczucia „uwięzienia”. Coraz częściej „kompromisowa machina” Unii Europejskiej postrzegana jest jako zinstytucjonalizowana, silna koalicja partii centrolewicowych i centroprawicowych, która to koalicja rutynowo ignoruje inne głosy polityczne [Bröning 2016].

Jak podaje raport Chatham House The Rise of Populist Extremism in Europe, populistyczne partie ekstremistyczne (PEP) stanowią jedno z najbardziej palących wyzwań dla europejskich demokracji. Partie, takie jak francuski Front National, Szwedzcy Demokraci czy austriacka Partia Wolności, nadal cieszą się dużym poparciem społecznym, nawet wśród dobrze wykształconych mieszkańców zamożnych regionów ${ }^{2}$. Częściej jednak wyborcami tych partii są gorzej wykształceni i słabsi ekonomicznie obywatele. Dlatego też wzrost popularności partii populistycznych często wiąże się ze wzrostem niepokojów społeczeństwa o utratę miejsc pracy, mieszkania socjalnego i zmniejszania zakresu działania państwa opiekuńczego. Główne konkluzje raportu sprowadzają się do stwierdzeń: (1) partie PEP są wspierane głównie przez niższe klasy średnie i nisko wykwalifikowanych lub niewykwalifikowanych przedstawicieli klasy robotniczej, obywateli, którzy nie posiadają kwalifikacji zawodowych i są w niepewnej ekonomicznie sytuacji; (2) obawy wobec imigrantów i strach związany z różnorodnością kulturową wynikają z przekonania, że imigracja, różnorodność kulturowa i mniejszości są niebezpieczne dla ich kultury narodowej; (3) partie w swoich działaniach mainstreamowe nie stosują w wystarczającym stopniu narzędzi i technik wykorzystywanych skutecznie przez partie PEP, to znaczy nie potrafią zbliżyć się do wyborców. Partie PEP, odsunięte od władzy przez ostatnie 20 lat, miały wiele czasu na wypracowanie strategii działania. Pozwoliło im to na wdrożenie bardziej innowacyjnych i skuteczniejszych metod reagowania niż te, którymi posługują się partie głównego nurtu. Do czasu, gdy partie mainstreamowe nie „odrobią lekcji“ i nie zaczną odpowiadać na faktyczne niepokoje wyborców, PEP - w szczególności w odniesieniu do wpływu kulturowego imigracji i rosnącej różnorodności - nadal będą cieszyć się znaczącym poparciem i mogą stać się partiami, na które głosować będą nowe pokolenia wyborców [Chatham House].

\section{W poszukiwaniu kierunku reform Unii Europejskiej}

\subsection{Więcej Francji}

Jedną z propozycji reformy UE jest opracowany kilka lat temu plan francuskiej prawicy. Koncepcja służyć ma „uratowaniu Europy” przed rozpadem. Propozycja w zasadzie sprowadza się do jednego hasła: „więcej Francji”. Francuski konserwatywny establishment chciałby, aby Unia Europejska była mniejsza, węższa, ograniczona

2 Więcej na: https://www.chathamhouse.org/media/news/view/178303\#sthash.R08EgCQS.dpuf (kwiecień 2017). 
w swoich kompetencjach i bardziej narodowa. Lider grupy Les Républicains (LR), Sarkozy, wskazał pięć kluczowych punktów dla reformy UE: (1) UE powinna zreformować współpracę w ramach Schengen w taki sposób, aby każdy kraj miał większą kontrolę nad własnymi granicami; (2) Europa powinna zaproponować własną wersję Międzynarodowego Funduszu Walutowego, aby uniknąć bycia uzależnioną od decyzji Stanów Zjednoczonych; (3) Komisja Europejska powinna być znacznie ograniczona w możliwości proponowania nowych regulacji prawnych; (4) parlamenty narodowe powinny mieć prawo do wetowania wszystkich propozycji Komisji Europejskiej; (5) powinna zdecydowanie dobiec końca „niekończąca się ekspansja” terytorialna Unii Europejskiej, co wiąże się z decyzją o nieprzyjmowaniu nowych państw do UE [Vinocur 2016]. W zasadzie koncepcja ta przypomina pod pewnymi względami wizję Europy de Gaulle'a, wyrażoną w obu wersjach planu Foucheta, choć oczywiście nie jest aż tak radykalna.

\subsection{Europa koncentrycznych kręgów}

Wielu obserwatorów nie ma wątpliwości, że koncepcja Europy koncentrycznych kręgów jest realistyczna i oznacza w rzeczywistości odejście od wizji ojców założycieli, zakładającej doskonałą równość między państwami członkowskimi, niezależnie od ich wielkości i siły.

Według tej koncepcji współpraca w zjednoczonej Europie przebiegałaby w sposób zróżnicowany pomiędzy poszczególnymi grupami państw, które w zależności od zaangażowania w proces integracji tworzyłyby określone „kręgi współpracy”. Najbardziej wewnętrzny krąg (rdzeń UE) byłby oczywiście oparty na grupie najsilniejszych państw, członków strefy euro. Część tych państw (przede wszystkim Niemcy) od dawna już nawołuje do wprowadzenia nowych, bardziej restrykcyjnych zasad rządzenia, wprowadzających środki zapobiegające nadmiernemu zadłużaniu się przez państwa członkowskie UE (vide casus Grecji). Wprowadzenie bardziej restrykcyjnych zasad dyscyplinujących budżety państw unijnych mogłoby prowadzić do wykształcenia się jakiejś formy „unii politycznej”, ponieważ zarówno wdrożone zasady, jak i ich egzekwowanie oznaczałoby ograniczenie suwerenności narodowej.

Kolejny krąg, położony najbliżej rdzenia, składałby się ze słabszych ekonomicznie krajów, ale nadal należących do strefy euro: Grecji, Portugalii i być może Hiszpanii. Ten pierścień mógłby również obejmować ekonomicznie silniejsze kraje skandynawskie, mimo że nie są one w strefie euro.

Polska, Węgry i coraz częściej Republika Czeska naruszają normy właściwe liberalnym demokracjom, naruszając zasady, na których opiera się istota integracji europejskiej. „Kraje, w których istnieje zagrożenie dla wolności słowa i pluralizmu politycznego, mogą zostać »sklasyfikowane« jako kraje, w których obywatelom (wyborcom) przekazywany jest sygnał ostrzegawczy: oddalacie się od integrującej się Europy" [Merritt 2016]. Kraje te, stanowiłyby ostatni, zewnętrzny krąg składający się z krajów członkowskich UE. 
Wreszcie ostatni, zewnętrzny pierścień składałby się z jednego państwa, którego nie będzie wkrótce w UE - Wielkiej Brytanii. Dotychczasowy poziom zintegrowania gospodarki brytyjskiej z krajami Unii Europejskiej oznacza de facto dalszy udział Zjednoczonego Królestwa w jednolitym rynku, choć na innych, nieznanych jeszcze, zasadach. Ostateczny kształt współpracy jest przedmiotem trwających negocjacji, nie jest jednak wykluczone utrzymanie czterech swobód (w tym swobodnego przepływu osób), a także zachowanie niektórych wkładów budżetowych (nawet jeśli zostaną wprowadzone korekty i zmiany pod tym względem).

\subsection{Pięć scenariuszy Komisji Europejskiej}

Komisja Europejska przedstawiła pięć scenariuszy przyszłości Unii Europejskiej w Białej Księdze poświęconej przyszłości Europy (White Paper on the Future of Europe. Reflections and scenarios for the EU27 by 2025) [European Commission 2017]. Scenariusze wahają się od najmniej proeuropejskiej opcji (ograniczonej do koncepcji wspólnego rynku - scenariusz 2) do pełniejszej i znacznie szybszej integracji (scenariusz 5). Scenariusze są zatytułowane: „Kontynuacja” („Carrying on”), „Nic poza jednolitym rynkiem” (,Nothing but the single market”), „Ci, którzy chcą więcej, robią więcej” (,Those who want more do more”), „Robić mniej, ale efektywniej” („Doing less more efficiently”) i „Robić wspólnie znacznie więcej” („Doing much more together"). Biała Księga jest wkładem Komisji, pod przewodnictwem przewodniczącego Jean-Claude'a Junckera, do toczącej się debaty na temat przyszłości UE. Dokument ten ma także wymiar symboliczny, ukazał się kilka dni przed Szczytem Rady Europejskiej, upamiętniającym 60. rocznice podpisania Traktatów Rzymskich [Ederi in. 2017].

\subsection{Europa wielu prędkości}

Europa wielu (różnych) prędkości w zasadzie jest już faktem od wielu lat. Kiedy na początku lat 90 . niektóre kraje postanowiły nie przyjmować wspólnej waluty w ramach protokołów dodatkowych do Traktatu z Maastricht, był to wstęp do braku jednolitej integracji wszystkich państw członkowskich. W okresie tak silnych nastrojów antyeuropejskich, które w przypadku Wielkiej Brytanii doprowadziły do opuszczenia Unii Europejskiej, konieczne jest wprowadzenie rozwiązań, które wzmocnią wewnętrznie UE. W tym kontekście bardzo ważnym wydarzeniem było zaproszenie Prezydenta Republiki Francuskiej François Hollande'a skierowane do premiera rządu Hiszpanii Mariano Rajoya, kanclerz Niemiec Angeli Merkel oraz premiera Włoch Paolo Gentiloniego na spotkanie „poświęcone refleksji nad przyszłością Unii Europejskiej 27 państw”, które odbyło się 6 marca 2017 roku, w Wersalu. W oświadczeniu prasowym wydanym po spotkaniu liderzy wprawdzie mówili w czterech językach, ale zasadniczo ,jednym głosem”. Ich wspólne stanowisko było wyraźnym wskazaniem na chęć realizacji scenariusza 3. Komisji Europejskiej, tak zwanej koncepcji Europy wielu prędkości („Ci, którzy chcą więcej, robią więcej”). 
Ukonstytuowana nieformalnie „grupa madrycka” (Niemcy, Włochy, Francja, Hiszpania), zamiast zbaczania w kierunku eurosceptycyzmu, wzywa do większej współpracy i integracji w stopniu, w jakim każdy kraj jest na to gotowy. Integracji „różnych prędkości" poddane miałyby być takie kwestie, jak: obronność, bezpieczeństwo, podatki i polityka społeczna. Spotkanie było zasadniczo pokazem jedności przed zbliżającymi się szczytami UE w Brukseli i Rzymie, a także spodziewanym powołaniem się przez Brytyjczyków na art. 50 (otwarcie procedury wychodzenia Wielkiej Brytanii z Unii Europejskiej w tym samym miesiącu, w którym miał się odbyć jubileuszowy Szczyt w Rzymie). Hollande nazwał wspólne stanowisko optowaniem za „zróżnicowaną współpracą”, Merkel wezwała kraje UE do zaakceptowania, „że niektóre kraje będą się integrować szybciej niż inne", Gentiloni natomiast powiedział, że powinniśmy pozwolić na „różne poziomy integracji”. Kanclerz Merkel podsumowała spotkanie stwierdzeniem: ,potrzebujemy optymizmu i większej zdolności do działania”. Dodała również: „musimy mieć odwagę, aby zaakceptować, że niektóre kraje chcą iść naprzód i mogą robić to trochę szybciej niż inne" [de la Baume, Herszenhorn 2017].

Niektóre kraje, w tym Polska, sprzeciwiają się koncepcji Europy wielu prędkości. Sprzeciw ten ma jednak charakter polityczny i jest uwarunkowany sporem z Komisją Europejską i Radą Europy (Komisja Wenecka), które to instytucje mają poważne wątpliwości co do zgodności działań rządu Polski z zasadami prawa. Obecny polski rząd jest zatem zainteresowany ograniczeniem ingerencji Europy i zawężeniem procesu integracji do spraw gospodarczych.

\section{Przyszłość Europy w oczach Europejczyków}

Biorąc pod uwagę postawy i opinie Europejczyków, możemy w zasadzie mieć pewność, że Unia Europejska jako projekt przetrwa i będzie dalej rozwijana.

Według Eurobarometru 2/3 Europejczyków (66\%) zgadza się z opinią, że UE jest ostoją stabilności w dzisiejszym trudnym świecie. Ze stwierdzeniem tym nie zgadza się 29\% badanych, a 5\% nie ma zdania na ten temat. Większość Europejczyków zgadza się, że narastanie ,przeciwstawnych” (antyeuropejskich) partii i ruchów jest powodem do obaw. Większość respondentów zgadza się, że partie polityczne sprzeciwiające się tradycyjnym wartościom europejskim w różnych krajach są powodem do obaw (59\%), a 21\% zgadza się z tym oświadczeniem w stopniu bardzo silnym [Eurobarometer 2016] ${ }^{3}$.

Pomimo wielu niedoskonałości, większość Europejczyków uważa, że Unia Europejska będzie w stanie łatwiej radzić sobie z problemami niż w sytuacji, gdyby to państwa członkowskie miały owe problemy rozwiązywać samodzielnie. Wśród

${ }^{3}$ Badanie Eurobarometer 451, The Future of Europe, przeprowadzono w formie bezpośrednich wywiadów między 24 września a 3 października 2016 r. Badanie obejmowało ogółem 27768 osób ze wszystkich państw członkowskich UE. 
problemów, które Europejczycy uznają za najpoważniejsze najczęściej wskazywano na bezrobocie i migrację (po 45\% wskazań). Migracja jest najdotkliwiej odczuwana przez obywateli Estonii (70\%), Węgier (65\%) i Malty (65\%). Blisko 1/3 obywateli UE jako poważny problem wskazuje także terroryzm (32\%). Na to zagrożenie (jako najpoważniejszy problem UE) wskazują przede wszystkim mieszkańcy Hiszpanii (33\% wskazań, natomiast w 21 państwach członkowskich terroryzm został wskazany jako drugi najpoważniejszy problem, z jakim musi uporać się Unia Europejska. Najsilniej zagrożenie terroryzmem odczuwane (wskazywane) jest w Republice Czeskiej (47\%), na Malcie (45\%) i na Łotwie (45\%). Imigracja i terroryzm wymieniane są jako pierwszy lub drugi najważniejszy obecnie problem UE we wszystkich państwach członkowskich, z wyjątkiem Portugalii, Włoch, Grecji, Danii, Szwecji i Finlandii ${ }^{4}$.

W swoim badaniu Eurobarometr poprosił również Europejczyków o wyrażenie opinii na temat koncepcji „Europy różnych prędkości”. Odpowiedzi były zdecydowanie podzielone. Niemal połowa badanych (47\%) twierdzi, że kraje, które są gotowe do zintensyfikowania rozwoju wspólnej polityki europejskiej w niektórych ważnych dziedzinach, powinny to robić bez oczekiwania na innych. $41 \%$ uważa, że kraje, które są na to gotowe, powinny poczekać, aż wszystkie państwa członkowskie UE osiągną tę gotowośćs.

\section{Podsumowanie}

Nie ulega wątpliwości, że Unia Europejska przeżywa obecnie kryzys. Jego przyczyny są złożone: rozczarowanie obecnym establishmentem, wzrostem popularności populistycznych i antyeuropejskich partii, kryzysem związanym z napływem emigrantów, a także trudną sytuacją na rynku pracy. Przełomem, który sprawił, że

\footnotetext{
${ }^{4} \mathrm{Z}$ badań Instytutu Gallupa wynika generalny wniosek: w Europie postawy wobec migracji pozostają w ścisłej korelacji z poziomem wykształcenia. Im wyższe wykształcenie (dyplom uniwersytecki), tym większa akceptacja, otwartość i zrozumienie dla napływu uchodźców. Europejczycy z wykształceniem średnim i niższym są mniej tolerancyjni wobec zjawiska migracji. Jednakże również wśród osób z wyższym wykształceniem opinie na ten temat są podzielone (46\% uważa, że migracja nie powinna być ograniczana, tyle samo wskazań opowiada się za jej ograniczeniem). Osoby z wykształceniem średnim lub niższym zdecydowanie opowiadają się za zmniejszeniem napływu migrantów [Esipova, Pugliese, Ray 2015].

${ }^{5}$ W 20 krajach członkowskich większość respondentów uważa, że kraje, które są gotowe do silniejszej integracji, powinny móc podejmować takie działania. Takiego zdania są przede wszystkim obywatele Holandii (77\%), Łotwy (65\%) i Szwecji (64\%). Najniższe poparcie dla Europy różnych prędkości wyrazili mieszkańcy Portugalii, (21\%), Hiszpanii (27\%) i Bułgarii (31\%). W siedmiu państwach członkowskich większość badanych uważa, że pogłębienie integracji powinno mieć miejsce wówczas, gdy wszystkie kraje będą na to gotowe: Portugalia (69\%), Hiszpania (62\%), Grecja (61\%), Rumunia (48\% vs. $41 \%$,powinny się integrować kraje, które tego chcą, bez czekania na pozostałe”), Polska ( $47 \%$ vs. $37 \%)$, Irlandia ( $46 \%$ vs. $42 \%)$ i Bułgaria ( $34 \%$ vs. $31 \%$, ale $35 \%$ obywateli nie ma zdania na ten temat) [Eurobarometer 2016].
} 
państwa członkowskie zdały sobie sprawę z potrzeby omówienia zmian w funkcjonowaniu UE, było referendum w sprawie brexitu. Był to wyraźny sygnał, że bez szybkiego działania politycznego projekt europejski może być poważnie zagrożony.

Trzeba jednak pamiętać, że debata nad reformą UE nie rozpoczyna się dziś. Dyskusja na ten temat toczy się od kilkunastu lat i staje się coraz głośniejsza - teraz jednak sytuacja wymaga podjęcia konkretnych działań. W artykule przedstawiono przegląd proponowanych kierunków reform Unii Europejskiej, które są często rozbieżne. Wydaje się, że najbardziej prawdopodobnym scenariuszem będzie koncepcja Europy różnych prędkości. Wskazuje to na kilka przesłanek: (1) w zasadzie od 1992 r. (Traktat z Maastricht), koncepcja ta jest już w toku; (2) jest popierana przez znaczną liczbą Europejczyków; (3) sprzyjają jej najsilniejsze państwa członkowskie (Niemcy i Francja).

Nie wydaje się prawdopodobne, abyśmy mogli odejść od postępów osiągniętych w procesie integracji. Między państwami członkowskimi istnieją silne i złożone relacje. Nie wydaje się także, aby Europejczycy oczekiwali osłabienia tych więzi. Biorąc pod uwagę wyniki wyborów w Holandii i wyniki wyborów prezydenckich we Francji, można powiedzieć, że wspólna i zjednoczona Europa, mimo wszystko, jest wartością, z której Europejczycy nie chcą zrezygnować. Według badania Eurobarometru (2016), UE cieszy się większym zaufaniem niż rządy krajowe. Co więcej:

- 66\% Europejczyków uważa, że UE jest miejscem charakteryzującym się stabilnością na tle niespokojnego świata. Ten pogląd podziela większość respondentów we wszystkich państwach członkowskich.

- $\quad 60 \%$ Europejczyków uważa, że projekt europejski daje młodym Europejczykom lepsze perspektywy na przyszłość i powinien być kontynuowany.

- $\quad 82 \%$ Europejczyków uważa, że gospodarka wolnorynkowa powinna iść w parze z wysokim poziomem ochrony socjalnej [Eurobarometer 2016].

Jednym z zagrożeń dla spójności europejskiej jest postawa rządów w Polsce i na Węgrzech. Jednakże rządy te powinny być traktowane jako pewien epizod i przykład (ostrzeżenie) dla innych państw, czym może kończyć się przekazywanie władzy partiom dalekim od europejskich wartości.

Europa z powodzeniem pokona ten kryzys i wyjdzie z niego jeszcze silniejsza. Nadchodzące lata będą czasem bliższej współpracy między krajami, które tego chcą, w ramach koncepcji Europy różnych prędkości. Wkrótce zaczną to odczuwać kraje, które nie chcą włączać się w te procesy. Wpłynie to również na życie ich obywateli, co znajdzie odzwierciedlenie w wynikach wyborczych partii pro- i antyeuropejskich.

\section{Literatura}

Baume M. de la, Herszenhorn D.M., 2017, n Versailles, EU's big 4 back multispeed Europe. Leaders of Germany, France, Italy and Spain call for greater integration - at your own pace, Politico, 3.06, http://www.politico.eu/article/in-versailles-eus-big-4-back-multi-speed-europe-italy-francegermany-spain/ (kwiecień 2017). 
Bröning M., 2016, The Rise of Populism in Europe. Can the Center Hold?, Foreign Affairs, 6 June, https:// www.foreignaffairs.com/articles/europe/2016-06-03/rise-populism-europe (kwiecień 2017).

ChathamHouse, The Rise of Populist Extremism in Europe, https://www.chathamhouse.org/media/ news/view/178303 (kwiecień 2017).

Dejevsky M., 2016, Brexit could finally spark reform of the EU, The Independent, 3 July.

Eder F., Heath R., Barigazzi J., Ariès Q., 2017, Commission outlines 5 scenarios for future of EU in white paper, Politico, 3.01, http://www.politico.eu/article/breaking-politico-obtains-white-paperon-eu-future/ (kwiecień 2017).

Esipova N., Pugliese A., Ray J., 2015, Europeans Most Negative Toward Immigration, Gallup Institute, October, http://www.gallup.com/poll/186209/europeans-negative-toward-immigration.aspx (kwiecień 2017).

Eurobarometer, 2016, The Future of Europe, December, http://ec.europa.eu/COMMFrontOffice/publicopinion/index.cfm/Survey/getSurveyDetail/instruments/SPECIAL/surveyKy/2131 (kwiecień 2017).

McDonald-Gibson Ch., 2016, The E.U. Agrees It Must Reform to Save Itself. But How? Time, June 27, White Paper on the Future of Europe. Reflections and scenarios for the EU27 by 2025, European Commission COM(2017)2025 of 1 March 2017.

Merritt G., Brexit calls for urgent EU reform, 13 July 2013, http://www.friendsofeurope.org/future-europe/frankly-speaking-brexit-calls-for-urgent-eu-reform/ (kwiecień 2017).

Vinocur N., 2016, The French Right's plan to save Europe: More France. Nicolas Sarkozy and his conservative rivals are all imagining the future of the EU, Politico, 7.01, http://www.politico. $\mathrm{eu} /$ article/the-french-rights-plan-to-save-europe-more-france-brexit-breakup-leave-eu-nicolassarkozy-les-republicains/ (kwiecień 2017).

Zwaan J. de, 2016, The European Union is in an existential crisis: how to get out?, TEPSA, September, http://www.tepsa.eu/category/publications/tepsa-publications/ (kwiecień 2017). 